\title{
De novo mutations in neurological and psychiatric disorders: effects, diagnosis and prevention
}

Julie Gauthier, ${ }^{1,2}$ and Guy A Rouleau',2,3*

\begin{abstract}
Neurological and psychiatric disorders account for a considerable proportion of the global disease burden. Although there is a high heritability and a significant genetic component in these disorders, the genetic cause of most cases has yet to be identified. Advances in DNA sequencing allowing the analysis of the whole human genome in a single experiment have led to an acceleration of the discovery of the genetic factors associated with human disease. Recent studies using these platforms have highlighted the important role of de novo mutations in neurological and psychiatric disorders. These findings have opened new avenues into the understanding of genetic disease mechanisms. These discoveries, combined with the increasing ease with which we can sequence the human genome, have important implications for diagnosis, prevention and treatment. Here, we present an overview of the recent discovery of de novo mutations using key examples of neurological and psychiatric disorders. We also discuss the impact of technological developments on diagnosis and prevention.
\end{abstract}

\section{The impact of de novo mutations in neurological and psychiatric disorders}

Neurological and psychiatric disorders account for 13\% of the global disease burden [1], directly affecting more than 450 million people worldwide. The prevalence of these disorders is likely to continue to increase as a result of the increasing life expectancy of the population. Improved diagnosis and treatment would translate into a significant improvement in the quality of life of a large

\footnotetext{
*Correspondence: guy.rouleau@umontreal.ca

'Center of Excellence in Neuroscience of the Université de Montréal , Quebec, Canada H2L 4MI

${ }^{2}$ Centre de Recherche du Centre Hospitalier de I'Université de Montréal, Quebec, Canada H2L 4MI

${ }^{3}$ Department of Medicine, Université de Montréal, Quebec, Canada H2L 4Ml
}

proportion of the population, as well as the reduction of disease-associated costs, yielding significant benefits at clinical and societal levels. For example, almost half of patients with schizophrenia are currently not receiving appropriate healthcare, in part because early symptoms are often confused with those observed in other psychiatric disorders (for example, psychotic depression or bipolar disorder [2]). Other disorders such as Rett syndrome (RTT) and neurofibromatosis type II (NF2) require a multidisciplinary approach in specialized treatment centers, thus leading to high healthcare costs that could be reduced if better treatments were available.

It has long been known that neurological and psychiatric disorders run in families, suggesting heritability with a major genetic component to the disease. For some neurological disorders, such as NF2 or RTT, the genetic cause has been identified. However, for the great majority of neurological and psychiatric disorders, such as schizophrenia, autism, bipolar disorder and restless legs syndrome, the genetic causes remain mostly unknown. Recent developments in DNA sequencing technologies have opened new windows into our understanding of the genetic mechanisms underlying these disorders. Using these high-throughput massively parallel DNA sequencing platforms (also called 'next generation') it is now possible in a single experiment to search for mutations in all genes of the human genome. A major discovery arising from the use of these platforms is the importance of $d e$ novo mutations (that is, acquired mutations in the offspring) in psychiatric disorders such as intellectual disability (ID) [3-5], autism [6-10] and schizophrenia [11-16]. Indeed, in many recent genome-scale studies, analyzing the genomes of affected individuals and comparing these with their parents' genomes showed that rare de novo coding and non-coding variations are significantly associated with risk for autism and schizophrenia $[6,8,10,12,17]$. The large number of new cases of these disorders has been hypothesized to partly result from de novo mutations that might compensate for allele loss due to severely reduced reproductive fitness, thereby maintaining high frequencies of these diseases [18].

The role of de novo mutations in human diseases has been well recognized, particularly in the area of cancer 
genetics and in dominant Mendelian disorders such as Kabuki and Schinzel-Giedion syndromes [19,20], both of which are characterized by severe ID and congenital facial abnormalities, and have recently been found to be caused by de novo mutations in MLL2 and SETBP1 genes, respectively. Surprisingly, de novo mutations are rather common (in the order of 100 new mutations per child), with only a few (in the order of one per child) in coding regions $[13,21]$, and have been found to be potentially disease-associated mutations (Table 1). De novo mutations outside coding regions, for example in promoter, intron or intergenic regions, can also be disease-associated. However, the challenge is to identify which of these mutations are pathogenic. Veltman and Brunner effectively summarized how interpretation of the pathogenicity of a de novo mutation should be established [18]. The following four major lines of evidence need to be taken into consideration when evaluating the pathogenicity of an observed de novo mutation: the de novo mutation rate, the gene function, the mutation impact and the clinical correlations (reviewed by Veltman and Brunner [18]). The main questions now are: How many genes will be involved in these disorders? What specific gene pathways are involved? What are the implications of de novo mutations for genetic counseling? These questions need to be investigated to improve diagnosis and to develop treatments.

In this review, we present an overview of the role of de novo mutations in neurological or psychiatric disorders. We use RTT, NF2 and schizophrenia to illustrate the different scenarios involving de novo mutations and how they can act and lead to a disorder. We also discuss how recent technological developments might influence how we make diagnoses, and we conclude by examining how prevention might be implemented in neurological and psychiatric disorders known to be linked to de novo mutations.

\section{Effects}

\section{Neurological and psychiatric disorders}

The brain governs the entire human body by controlling thoughts, memory, speech, movements and autonomic functions. Any deficiency at the level of one of these functions and/or structures, including neurons, cerebral blood vessels or meninges, is likely to lead to a 'brain disorder'. A brain disorder refers to a large category of illnesses and includes diseases characterized by various clinical symptoms, severities and ages of onset. This group includes neurological and psychiatric disorders (for example, NF2, schizophrenia, RTT and many others), which are the focus of this article. Neurological disorders affect the nervous system and psychiatric disorders are largely defined by patterns of abnormal thoughts and emotions, and maladaptive behavior and social interaction.
More than 600 such disorders have been defined, including 300 psychiatric disorders indexed in the Diagnostic and Statistical Manual of Mental Disorders (DSM) [22], the standard diagnostic tool for psychiatric disorders. Both groups of disorders are currently diagnosed by a physician based on clinical symptoms. Unfortunately, for the great majority of these disorders, no biological test is available. In addition, most of these disorders are complex, resulting from the interplay of genetic and environmental factors.

\section{Genetic perspectives}

Based on evidence from twin studies, the heritability of some disorders has been observed to be high. This is the case for autism and schizophrenia, with heritabilities in the order of $90 \%$ [23] and 80\% [24], respectively. However, these diseases also frequently occur as isolated cases, with only one affected child born to unaffected parents with no family history of the disease. One possible explanation is the occurrence of 'de novo' mutations, where mutations occur during spermatogenesis or oogenesis (germline mutations), and are therefore present in the patient but undetectable in the unaffected parent. This genetic mechanism has recently been the focus of considerable attention to explain part of the genetic basis of neurodevelopmental disorders.

According to the Allen Human Brain Atlas database [25], more than $82 \%$ of all human genes are expressed in the brain. Given that the human genome is estimated to contain 22,333 genes [26], this suggests that more than 17,800 genes are expressed in the human brain. Mutations affecting almost any of these genes, combined with environmental factors, may contribute to brain disorders. Recent studies have identified a number of causal mutations in brain-expressed genes and have revealed the considerable role that genetics plays in neurological and psychiatric disorders. These studies have highlighted the involvement of rare ( $<1 \%$ frequency) point mutations and copy-number variations (CNVs; that is, genomic deletions or duplications of $>1 \mathrm{~kb}$ to several $\mathrm{Mb}$ in size) that can occur in gene-free regions, or which may affect one gene or include a contiguous set of genes in the genetic etiology of autism, schizophrenia, ID, attention deficit disorder and other disorders [3,6-11,13,15,16,27-29]. Using studies of trios (that is, affected child and parents) with sporadic schizophrenia or autism (that is, with no history of psychiatric disorders in the parents or the extended family), we and others have observed a significant excess of potentially deleterious de novo mutations in the cases. Recently, the studies of Sanders et al., Neale et al., O'Roak et al. and Iossifov et al. have confirmed the contribution of de novo mutations to autism [6,8-10]. Each study identified a list of de novo mutations present in probands, but only a handful of genes were identified 
Table 1. Examples from the literature of human brain disorders and genes implicated in diseases associated with de novo mutations

\begin{tabular}{lcll}
\hline Disorders & OMIM & Implicated gene(s) & References \\
\hline Alexander disease & $\# 203450$ & GFAP & Brenner et al., 2001 [73] \\
Amyotrophic lateral sclerosis & $\# 105400$ & FUS, TDP-43, SOD1 & DeJesus-Hernandez et al., 2010 [74] \\
Ataxia & $\# 208920$ & CACNA1A, TBP & Koide et al., 1999 [75] \\
Autism spectrum disorders & $\# 209850$ & NLGN3, NLGN4, NRXN1, SHANK3, etc. & Jamain et al., 2003 [67]; Durand et al., 2007[39] \\
CADASIL & $\# 125310$ & NOTCH3 & Joutel et al., 2000 [76] \\
Cerebral cavernous malformations & $\# 116860$ & KRIT1, CCM2, CMM3, PDCD10 & Lucas et al., 2001 [77]; Bergametti et al., 2005 [78] \\
Charcot-Marie-Tooth disease & $\# 606482$ & $>10$ genes & Boerkoel et al., 2002 [79] \\
Dejerine-Sottas & $\# 145900$ & PMP22 & Valentijn et al., 1995 [80] \\
Dravet syndrome & $\# 607208$ & SCN1A & Claes et al., 2001 [81] \\
Early-onset dementia & $\# 600274$ & PRNP, APP & Cannella et al., 2007 [82]; MCNaughton et al., 2012 [83] \\
Focal epilepsy & $\# 300088$ & SCN1A & Okumura et al., 2007 [84] \\
Hemiplegic migraine & $\# 141500$ & ATPA2, CACNA1A & Riant et al., 2010 [85] \\
Intellectual disability & $\# 612621$ & SYNGAP1 & Hamdan et al., 2009 [4] \\
Neurofibromatosis type II & $\# 162200$ & NF1 & Viskochil et al., 1990 [86] \\
Neurofibromatosis type II & $\# 101000$ & NF2 & Rouleau et al., 1993 [53] \\
Rapid-onset dystonia Parkinsonism & $\# 128235$ & ATP1A3 & Post et al., 2009 [87] \\
Rett syndrome & $\# 312750$ & MECP2, CDKL5 and netrin G1 & Amir et al., 1999 [44]; Weaving et al., 2004 [88]; Borg et al., 2005 [89] \\
Schizophrenia & $\# 181500$ & SHANK3, NRXNs & Gauthier et al., 2010 [14]; RujesCu et al., 2009 [90] \\
\hline
\end{tabular}

with multiple de novo hits (that is, $C H D 8, S C N 2 A$, KATNAL2 and NTNG1 genes). Protein-interaction network and pathway-based analyses from these studies showed significant connectivity and a common biological pathway among genes harboring de novo mutations in cases with autism. Protein networks implicated in chromatin remodeling, ubiquitination and neuronal development have been identified as potential targets for autism susceptibility genes. Finally, these studies suggest that 1,000 or more genes may be implicated as those in which highly penetrant autism-contributing mutations can occur [6,8-10].

\section{De novo mutations: roles, causes and implications}

Technological advances in DNA sequencing have revolutionized the study of genetic variation in the human genome and have allowed the identification of many types of mutations, including single-base pair substitutions, insertions/deletions, CNVs, inversions and repeat expansions, as well as both somatic and germline mutations. All these types of mutations have been shown to play a role in human disease. Single nucleotide mutations appear to be largely of paternal origin, whereas deletions may be largely of maternal origin. This could be explained by the differences between male and female gametogenesis. For example, in a study of neurofibromatosis, 16 of 21 mutations consisted of deletions of maternal origin and 9 of 11 point mutations were of paternal origin [30].
The various mutation types can either be transmitted from a parent to a child or acquired spontaneously. The mechanism directing the latter has attracted attention in recent years due to the importance of this type of mutation in diseases such as schizophrenia and autism. The rate of de novo mutations appears to be dominated by the age of the father [31]. The rate increases with increasing paternal age, possibly due to the consequences of reduced efficiency of DNA replication or repair mechanisms, which are expected to deteriorate with age $[31,32]$. Therefore the risk for a disease should increase with increasing paternal age. This has been found to be the case in many disorders, including Crouzon syndrome [33], multiple endocrine neoplasia type II [34] and neurofibromatosis type I [35]. More recently, O’Roak et al. observed a marked paternal bias of 51 de novo mutations identified through an exome sequencing study of 189 parent-child trios with cases of sporadic autism. Their findings are similar to those observed from recent reports on de novo CNVs in ID [36]. This correlation could be explained by the significantly higher number of mitotic cell divisions in germ cells or spermatocytes prior to meiosis over the lifetime of men, compared with that which occurs in oogenesis in women. Based on the established number of cell divisions occurring in oogenesis (from birth to menopause) compared with spermatogenesis (from puberty to the end of life), James F. Crow estimated that by age 30 years the average number of 
chromosome replications from the zygote to sperm formation is 16.5 -fold higher than from zygote to ovum formation [37].

\section{Mosaicism and recurrent risk of disease}

Genetic mosaicism is caused by the occurrence of de novo mitotic mutations very early in the development of the embryo and is defined as the presence of multiple cell clones with a distinct genotype in the same individual. Both somatic and germline mosaicism exist, but germline mosaicism may contribute to the transmission of what might appear to be a de novo mutation to the offspring. Germline mosaicism involving the SHANK3 gene has been described by our group in a schizophrenia kindred [14]. We detected a nonsense de novo (R1117X) mutation in a proband and his two affected brothers that appeared to be paternally inherited based on haplotype analysis, and is likely to be due to germline mosaicism. This phenomenon has been documented in more than 60 genetic diseases, including many brain disorders [38]. For example, Durand et al. and Moessner et al. reported families with two affected siblings with apparently healthy parents, carrying the same de novo frame-shift SHANK3 mutation and the same de novo $4.4 \mathrm{Mb}$ deletion, respectively $[39,40]$. In both cases, the mutation was absent in blood DNA of the unaffected parents. In these cases where unaffected parents have multiple affected children carrying the same de novo mutation, germline mosaicism is inferred. Parental allelic origin can be determined using molecular cloning and informative markers in one of the parents that are linked to the de novo events. One would normally expect the risk of the same de novo mutation occurring in a subsequent sibling to be equivalent to zero or to be smaller than the de novo mutation rate baseline estimate of $1.1 \times 10^{-8}$ to $1.2 \times 10^{-8}$ $[13,31,41,42]$, which is the frequency of new single nucleotide variants per generation in humans. However, this is not the case when germline mosaicism exists. In a literature review on germline mosaicism, Helderman-van den Enden $e t$ al. found that among seven diseases with known recurrence risk for de novo mutation, the risk of recurrence due to germline mosaicism varied from $0.02 \%$ in achondroplasia to $11 \%$ in RTT, $13 \%$ in hemophilia A and $20 \%$ in Duchenne muscular dystrophy [38]. The reason why recurrence risk varies significantly from one disease to another remains obscure. Unfortunately, for most diseases the recurrence risk of de novo mutations originating from germline mosaicism has not been studied. This information will be important for genetic counseling, where a reliable estimate of recurrent risk is needed.

Spontaneous mutations arising in somatic cells (during mitosis, after fertilization) may also play a role in neurodevelopmental diseases. Such mutations would not normally be passed to the offspring, except if they occurred in cells that later formed the germline. Thus, throughout life, in addition to inherited mutations, an individual will accumulate genetic mutations in many different cells. Somatic mutations result from factors that include defective DNA repair or DNA replication, and agents that damage DNA, such as exposure to radiation, cigarette smoke or certain drugs. Next-generation sequencing technologies are now allowing researchers to better study the prevalence of somatic mutations and their involvement in disease [43].

\section{De novo mutations in neurological and psychiatric disorders: three possible scenarios}

As mentioned earlier, de novo mutations can be of various types and can originate from paternal or maternal chromosomes. In addition, these mutations can act in dominant or recessive manners, as well as in combination with somatic de novo mutations. This section aims to illustrate these different scenarios based on RTT, NF2 and schizophrenia as examples of diseases associated with de novo mutations (Figure 1).

\section{RTT: one gene}

RTT is one of the most common causes of severe ID in girls, with an incidence of 1:10,000 live female births. Most cases of RTT are sporadic, with no familial history of the disease. We now know that the majority of patients with RTT have a de novo mutation in the X-linked gene encoding methyl CpG binding protein 2 (MECP2) [44]. Most of these de novo mutations arise on the paternal $\mathrm{X}$ chromosome $[45,46]$, increasing in frequency with paternal age, which is consistent with the hypothesis that point mutations occur more frequently during spermatogenesis than oogenesis. Very few families have been described with multiple affected individuals, but these have typically involved siblings (for example $[47,48]$ ) where transmission occurs from asymptomatic mothers with skewed X-chromosome inactivation [48] or by parental gonadal mosaicism [49]. Thus, the example of RTT clearly illustrates that, for neurological or psychiatric disorders, new mutations can act in a dominant manner to cause disease.

\section{Schizophrenia: multiple genes}

Schizophrenia is a chronic and severe mental illness characterized by profound disruption in cognition, behavior and emotion. Although there may be some variations, the prevalence of schizophrenia is reported to be $1 \%$ in the population over the age of 18 years [50], a frequency that is maintained across different ethnic groups, cultures and geographic regions [51]. Schizophrenia is a complex brain disorder suspected to result from both genetic and environmental influences. Recent advances in sequencing technologies have greatly helped 
(a)

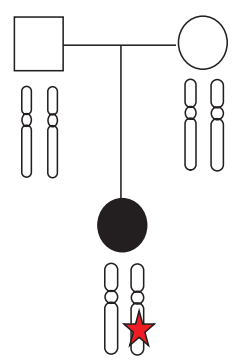

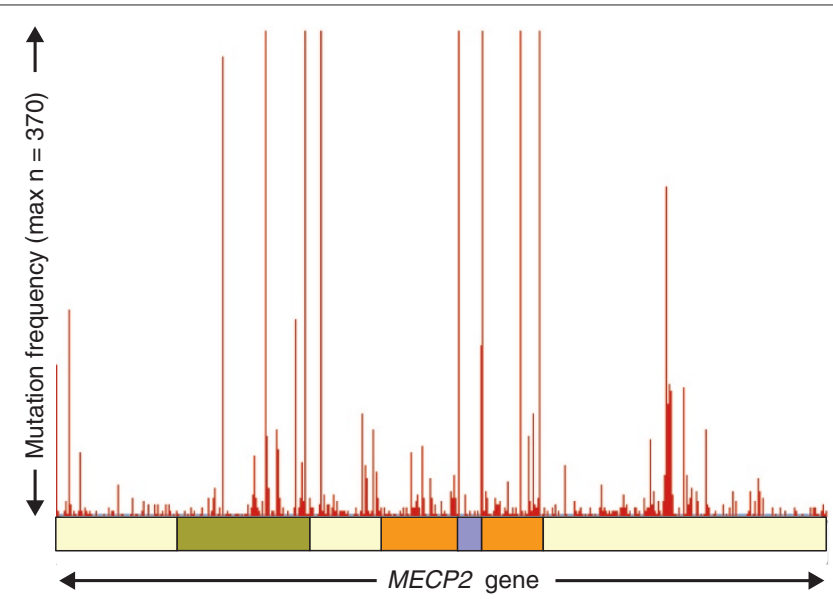

(b)

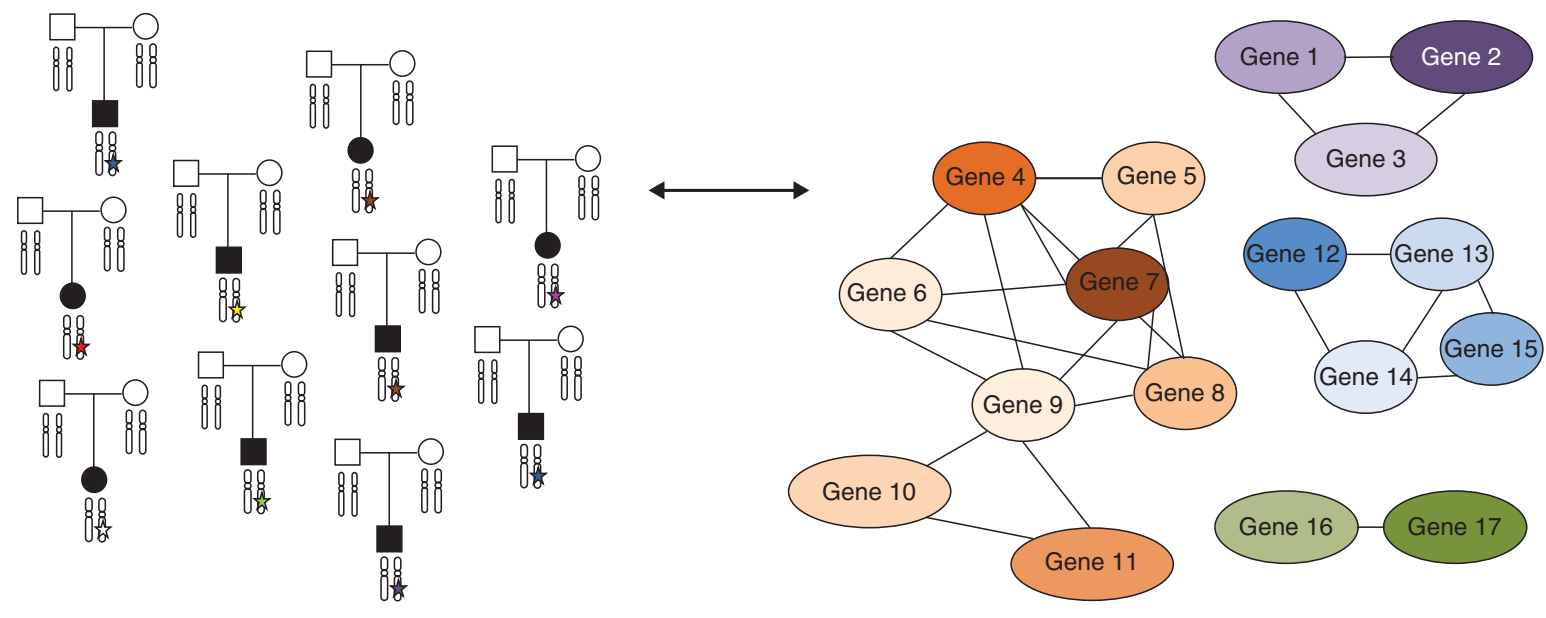

(c)
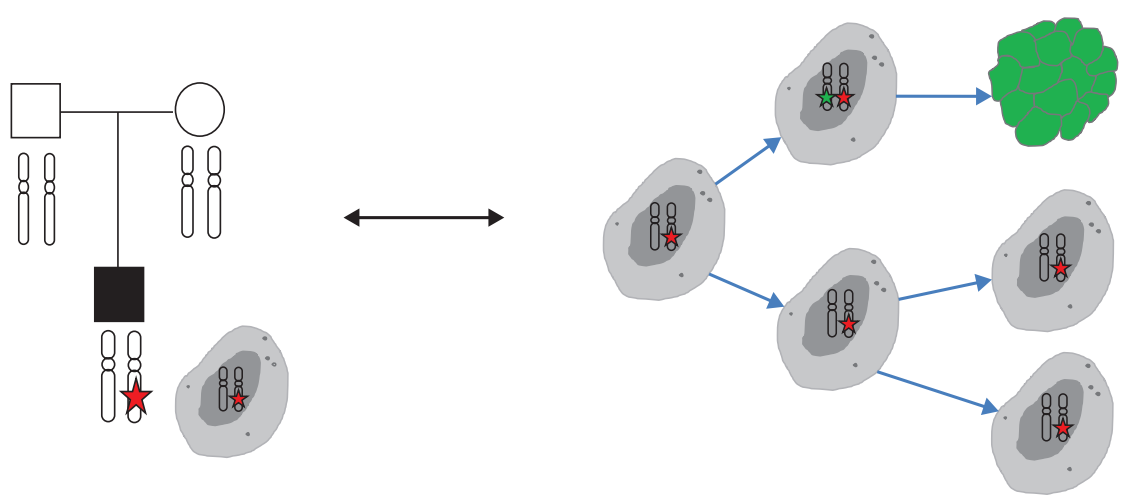

Figure 1. Schematic representation of de novo mutations and three genetic mechanisms. Example (a) represents the case of one gene (here, the gene encoding methyl CpG binding protein 2, MECP2), and the occurrence of multiple de novo mutations in unrelated subjects with Rett syndrome (vertical bars in graph on the right). The green, orange and purple shaded areas illustrate the methyl-CpG binding domain, the transcriptional repression domain and the nuclear localization signals, respectively. Example (b) demonstrates a current hypothesis for schizophrenia, where the majority of the de novo mutations identified in schizophrenia cases occur in different genes. These genes are likely to be part of specific networks or pathways. The last example (c) shows the 'double hit' de novo model observed in neurofibromatosis type II. Fifty percent of neurofibromatosis type II cases are caused by an acquired de novo mutation present in all cells (red star), and in some cells a second somatic de novo mutation occurs, which inactivates the normal copy of the neurofibromatosis gene (green star). Cells harboring the two hits (red and green) will lead to a tumor represented by the cluster of green cells. 
to strengthen the importance of the role of rare de novo variants in schizophrenia. As an example, to investigate the possibility that de novo protein-altering mutations contribute to the genetic component of schizophrenia, $\mathrm{Xu}$ et al. and Girard et al. sequenced the exomes of 53 and 14 sporadic cases and their parents, respectively $[11,12]$. The studies' results were concordant. Although not all de novo mutations are necessarily pathogenic, some of the ones identified in these studies are likely to be responsible for the schizophrenia phenotype based on several lines of evidence, such as the observed large excess of non-synonymous de novo point mutations compared with neutral ones, and the observed enrichment of predicted deleterious non-synonymous variants (relative enrichment 12.1; chi-squared test, $P<0.0001$ [12]). It is interesting to note that the majority of the de novo mutations associated with susceptibility to schizophrenia to date occur in many different genes. Thus, the sporadic form of schizophrenia seems to be associated with multiple genes, suggesting a high level of non-allelic genetic heterogeneity. This might explain why the global incidence of schizophrenia is relatively uniform, and the disease is maintained at a similar frequency despite extremely variable environments and poor reproductive fitness [52].

\section{NF2: two-hit model}

NF2 is a rare monogenic disorder characterized by bilateral vestibular schwannomas as well as other spinal and peripheral tumors. The tumor suppressor gene NF2, which maps to chromosome 22q11.2, was isolated in 1993 by two independent groups [53,54]. Nearly $50 \%$ of cases represent new mutations in individuals with no family history of the disease. Individuals with NF2 have one copy of the gene inactivated in all their cells; for tumor development specific cells need to have a somatic de novo mutation(s), which inactivates the normal copy of the NF2 gene. In the case of sporadic schwannomas, specific cells need to have somatic mutations inactivating both copies of the NF2 gene. Hence, the disease is inherited in a dominant manner, but acts in a recessive manner at the cellular level. Knudson proposed this 'twohit' model early in 1971 from his observations in retinoblastoma [55].

As discussed earlier, de novo mutations can lead to a monogenic dominant (for example, RTT) or monogenic recessive (for example, NF2) Mendelian form of disease, and even to a form of disease in which a large number of different genes is implicated (schizophrenia). The latter mechanism is expected to be prominent in other psychiatric disorders such as autism, ID and bipolar disorder.

\section{Diagnosis}

Next-generation DNA sequencing technologies are now commonly used in research, and an increasing number of institutions and clinical laboratories are offering molecular genetic analysis based on this method. These tests may be used to identify disease-predisposing mutations or to identify genetic variants that might in part predict development of diseases as well as indicate those individuals who are most likely to respond to specific medications or interventions.

\section{The role and impact of technological developments}

Whole genome and exome sequencing are powerful research tools to identify predisposing genes underlying a variety of disorders where other conventional methods have limited success. The main reason for the previous lack of success is allelic and non-allelic genetic heterogeneity, with dozens to perhaps hundreds of genes predisposing to each diagnostic entity, and each gene having many allelic variants. This is exemplified by recent studies of autism using parent-child trios [6,8-10]. Mutations in genes predisposing to severe diseases where there is a strong negative selection against the phenotype, such as lethality in embryonic stages or reduced reproductive fitness, will not be transmitted to multiple family members, and therefore will not be detected by gene linkage mapping.

The successful use of whole genome and exome sequencing for diagnosis has been confirmed in numerous studies. Whether exome sequencing will eventually be replaced by whole genome sequencing is still unknown. Although most mutations are found in coding regions, it is thought that both exome and whole genome sequencing will coexist [56]. Interestingly, based on sequencing the same sample, Clark et al. demonstrated that exome and whole genome sequencing are complementary. Exome sequencing can detect variants not detected by whole genome sequencing and vice versa [57]. However, an important challenge in using whole genome sequencing will be the interpretation of the data. We expect that whole genome sequencing will allow the identification of genetic variants that will determine an individual's risk of developing diseases, including neurological or psychiatric disorders. In fact, the continuing reduction in sequencing costs may lead to replacement of most of the other currently used approaches.

\section{Prenatal diagnosis}

The rapid development of sequencing is now having a positive impact on prenatal diagnosis. Since the discovery of cell-free fetal nucleic acids circulating in the blood of pregnant women [58], combined with the development of next-generation DNA sequencing technologies, it is now possible to perform early, non-invasive prenatal genetic testing [59]. The major advantage is to provide genetic information about the fetus avoiding a health risk due to the current invasive approaches, such as 
amniocentesis. In addition to causing stress for pregnant women, performing this invasive procedure and the analyses are costly, and entail a significant fetal loss rate of 0.5 to $1 \%[60,61]$. Thus, implementing sequencing technologies and approaches would have numerous clinical advantages. Clinical applications of these methods already include fetal sex determination and blood group typing [62]. Ongoing research is evaluating the use of this approach for non-invasive detection of trisomies [63]. Other uses being explored are the detection of singlegene disorders, a range of chromosomal abnormalities and inheritance of parental polymorphisms across the whole fetal genome. Two groups have recently demonstrated that it is now technically feasible to non-invasively sequence the entire fetal genome [64,65]. While technical, analytical and ethical challenges remain, it is likely that this approach will be integrated into clinical practice in the near future.

\section{Clinical versus genomic diagnosis}

Most disorders are clinically defined and diagnostic tools aim at facilitating the 'clinical diagnosis'. A 'genomic diagnosis' is based on the analysis of the genetic information contained in the patient's DNA to determine whether the patient carries a genetic defect associated with a disease. Genomic approaches offer the opportunity to identify risk factors prior to or very early after disease onset, allowing earlier and more efficacious interventions focused on prevention rather than treatment. Establishing an accurate diagnosis is the foundation on which medicine is based. Upon learning that their child has a disorder, most parents wish to understand the cause of the condition and are concerned about the risk of recurrence in other offspring. Diagnostic techniques based on molecular genetics provide concrete answers to these questions. Establishing an accurate diagnosis based on genetic analysis presents significant advantages, reducing the usual battery of tests required to pinpoint the cause of a disorder. For example, children with ID typically undergo a series of investigations, brain imaging, metabolic studies, cytogenetic and molecular genetics testing, to make an etiological diagnosis. A high performing genomic test introduced at the beginning of this process may obviate the need for costly, time-consuming and stressful assessments in a large proportion of cases.

While mutations in hundreds of susceptibility genes have already been described in brain disorders, genetic diagnostic assays are available for only a handful of genes. As an example, although non-syndromic ID could represent up to two-thirds of all ID cases, only about 50 causative genes have so far been identified [66], which explain less than $10 \%$ of sporadic cases, suggesting that the total number of non-syndromic ID genes is likely to be in the hundreds. It is now clear that the same clinical diagnosis may not necessarily be given for the same genetic/genomic defect. This is indeed the case for the majority of brain disorders where de novo mutations occur in different genes. By contrast, a single gene may lead to different diagnoses. For example, one de novo mutation in the X-linked NLGN3 gene has been found to occur in an asymptomatic mother, who had two affected sons, one diagnosed with autism and the other with Asperger syndrome [67]. Although these disorders are clinically related, they correspond to distinct diagnoses in the current version of the DSM-IV [22]. As discussed by Boone et al. in a review of genomic medicine and neurological diseases [68], these observations bring us to ponder whether individuals may one day be given two distinct (or complementary) diagnoses: one clinical in nature, the other molecular. Guidelines for de novo mutation screening analysis, and more importantly, guidelines for mutation interpretation, will need to be elaborated as more and more laboratories will be offering exome or whole genome analysis for diagnostic purposes. Clearly, additional work is needed to establish lists of disease causative or predisposing genes, which should be part of diagnostic tests of genetically heterogeneous disorders. For example, determining mutation prevalence (for a range of specific mutations, as well as mutational frequency of any single gene), or the frequency at which any particular gene leads to any single phenotype, remains to be defined for most diseases. Both the clinical and genomic approaches aim to achieve diagnosis of a disease, and we consider that both approaches will remain complementary in the future.

\section{Limitations and ethical issues}

Although technically feasible, several challenges remain for using whole genome sequencing for diagnosis. Nextgeneration DNA sequencing technologies generate terabytes of data, and storing the amount of data that will be produced constitutes a challenge. In addition, processing these huge amounts of genetic information requires upto-date computational power and time resources. Bioinformatic analysis still remains a bottleneck and negatively impacts on the 'turnover' time for giving results to patients. The major challenge remains the interpretation of data and linking the genetic variant to the disease.

Important ethical challenges also remain. For example, should incidental findings (that is, those found accidentally and not related to the disease being tested) identified by whole genome or exome sequencing be reported to the patient? There is currently no consensus regarding this issue in the field. In fact, whole human genome sequencing adds to the complexity of the genetic information that will be accessible, and raises great social concerns that still need to be resolved, such as possible forms of discrimination. Efforts have been made to 
overcome this phenomenon since the Genetic Information Nondiscrimination Act was signed in the USA in 2008 to protect individuals from improper use of genetic information with regard to health insurance and employment [69]. Emerging discoveries of susceptibility genes and gene variants associated with major neurological or psychiatric disorders are likely to challenge the existing ethical guidelines. It is up to researchers, health professionals and experts in Ethical, Economic, Environmental, Legal, and Social aspects of genomics (GE3LS) to manage this growing scientific knowledge in a way that prioritizes protection of research participants and improves patient care.

\section{Prevention and treatment}

The identification of predisposing disease genes is essential to identify the disease-predisposing biological pathways. Early diagnosis opens avenues for interventions that could delay or prevent the development of neurological or psychiatric disorders. For example, an accurate molecular diagnosis in a patient with ID may lead to interventions that may result in improving the patient's intellectual abilities, making the difference between the need for permanent institutionalization and the ability to live and work with minimal intervention from caregivers.

If de novo mutations are indeed important contributing factors for neurological and psychiatric disorders, one issue that needs to be addressed is the identification of the factors contributing to higher mutation rates. Prevention may only be achieved once the 'mechanisms' underlying the cause of a disease are recognized. Parental age at the time of conception may be one factor contributing to a higher mutation rate. This has been recently confirmed by Kong et al., who showed that the father's age is the dominant factor in determining the number of de novo mutations in a child [31]. By sequencing the entire genomes of 78 parent-child trios, including five families comprising three generations, Kong et al. found that the number of mutations increases with the father's age $\left(P=3.6 \times 10^{-19}\right)$ with an estimated linear effect of 2.01 mutations per year (standard error $=$ 0.17 ), and an estimated doubling of paternal mutations every 16.5 years using an exponential model [31]. Other 'environmental' factors that may also be associated with de novo mutations need to be identified.

One of the future challenges will be to determine how genomic information may be used to predict the risk for developing medical conditions. Concomitantly, one must define the best ways and develop the best tools to manage this information and use it to improve quality of life and care of patients. This will be even more critical when translating this information into preventive measures aimed at achieving improved health. Given that new targeted treatments focusing on correcting (fully or partially) genetic defects are likely to be available in the near future (for example, gene therapy for the treatment of frame-shifting mutations using antisense-induced exon skipping to restore the reading frame [70]), an accurate genetic diagnosis will inevitably define the appropriate treatment.

\section{Conclusions and future directions}

The availability of genomic information has increased significantly over the last decade through the development of high-throughput DNA sequencing technologies. The accessibility of these platforms has allowed an acceleration of the rate of discovery of DNA variations associated with disease. Therefore the number of genes being associated with brain disorders is increasing at an unprecedented rate. In other words, these techniques have completely changed gene identification approaches from single-gene screening to whole genome screening, and have become a powerful tool to identify disease genes, particularly where conventional methods have failed. The discovery of genetic variants underlying neurological and psychiatric disorders provides insights into disease mechanisms. A good example is the recent finding of the important role of de novo mutations in psychiatric disorders such as schizophrenia and autism. This discovery was only possible (or at least accelerated) with the ability to sequence the exome of an affected child and compare it with his/her parents. Although the role of de novo mutations in neurological and psychiatric disorders has been confirmed by several independent studies, many issues remain to be resolved. For example, what are the causes of de novo mutations? What is the percentage of cases affected by deleterious de novo mutations? Are certain genomic regions or certain genes more frequently prone to de novo mutations? All of these questions will be answered with the increasing amounts of exome or whole genome data available for analysis.

In turn, these discoveries will enable the development of improved diagnosis. However, the clinical use of diagnostic tests derived from these discoveries is lagging behind. One of the major challenges is to develop tools and methods that will help improve medical diagnosis. Knowing which genes are disrupted in a brain disorder such as autism will allow molecular diagnostic assays to be developed to better identify and define pathogenesis in affected individuals, and to do so at an earlier age.

Any new understanding of the pathological mechanisms of brain diseases is important for medicine and directly impacts the community. Early intervention in neurological or psychiatric disorders is likely to have a significant impact on outcome. Indeed, without effective intervention, most people with autism and other pervasive developmental disorders require lifelong specialized educational and care services, at a total cost that is 
estimated at approximately US\$4 million per person [71]. The overall average savings from the implementation of an early intensive behavioral intervention program, such as a one-to-one behavioral-based treatment for children with autism, are estimated at US\$1 to 2 million per individual across their lifespan, without taking into account the human benefits [72]. Finally, establishing a definite genetic diagnosis of a disease, especially in children, can significantly reduce the levels of guilt and anxiety in parents and improve their compliance with educational intervention programs.

\section{Abbreviations}

CNV, copy-number variation; DSM, Diagnostic and Statistical Manual of Mental Disorders; ID, intellectual disability; NF2, neurofibromatosis type II; RTT, Rett syndrome.

\section{Competing interests}

The authors declare that they have no competing interests.

\section{Acknowledgements}

G.A.R. holds the Canada Research Chair and the Jeanne-et-J.-Louis-Levesque Chair for the Genetics of Brain Diseases. We wish to thank Fadi F. Hamdan and Anna Bonnel for their critical reading prior to publication of this review.

\section{Published: 25 September 2012}

\section{References}

1. Organisation mondiale de al Santé [http://www.who.int/fr/]

2. van Os J, Kapur S: Schizophrenia. Lancet 2009, 374:635-645.

3. Vissers LE, de Ligt J, Gilissen C, Janssen I, Steehouwer M, de Vries P, van Lier B, Arts P, Wieskamp N, del Rosario M, van Bon BW, Hoischen A, de Vries BB, Brunner $\mathrm{HG}$, Veltman JA: A de novo paradigm for mental retardation. Nat Genet 2010, 42:1109-1012.

4. Hamdan FF, Gauthier J, Spiegelman D, Noreau A, Yang Y, Pellerin S, Dobrzeniecka S, Côté M, Perreau-Linck E, Carmant L, D'Anjou G, Fombonne E, Addington AM, Rapoport JL, Delisi LE, Krebs MO, Mouaffak F, Joober R, Mottron L, Drapeau P, Marineau C, Lafrenière RG, Lacaille JC, Rouleau GA, Michaud JL; Synapse to Disease Group: Mutations in SYNGAP1 in autosomal nonsyndromic mental retardation. N Engl J Med 2009, 360:599-605.

5. Hamdan FF, Gauthier J, Araki Y, Lin DT, Yoshizawa Y, Higashi K, Park AR, Spiegelman D, Dobrzeniecka S, Piton A, Tomitori H, Daoud H, Massicotte C, Henrion E, Diallo O; S2D Group, Shekarabi M, Marineau C, Shevell M, Maranda B, Mitchell G, Nadeau A, D'Anjou G, Vanasse M, Srour M, Lafrenière RG, Drapeau P, Lacaille JC, Kim E, Lee JR, et al.: Excess of de novo deleterious mutations in genes associated with glutamatergic systems in nonsyndromic intellectual disability. Am J Hum Genet 2011, 88:306-316.

6. Sanders SJ, Murtha MT, Gupta AR, Murdoch JD, Raubeson MJ, Willsey AJ, Ercan-Sencicek AG, DiLullo NM, Parikshak NN, Stein JL, Walker MF, Ober GT, Teran NA, Song Y, El-Fishawy P, Murtha RC, Choi M, Overton JD, Bjornson RD, Carriero NJ, Meyer KA, Bilguvar K, Mane SM, Sestan N, Lifton RP, Günel M, Roeder K, Geschwind DH, Devlin B, State MW: De novo mutations revealed by whole-exome sequencing are strongly associated with autism. Nature 2012, 485:237-241.

7. Sanders SJ, Ercan-Sencicek AG, Hus V, Luo R, Murtha MT, Moreno-De-Luca D, Chu SH, Moreau MP, Gupta AR, Thomson SA, Mason CE, Bilquvar K, CelestinoSoper PB, Choi M, Crawford EL, Davis L, Wright NR, Dhodapkar RM, DiCola M, DiLullo NM, Fernandez TV, Fielding-Singh V, Fishman DO, Frahm S, Garagaloyan R, Goh GS, Kammela S, Klei L, Lowe JK, Lund SC, et al:: Multiple recurrent de novo CNVs, including duplications of the $7 q 11.23$ Williams syndrome region, are strongly associated with autism. Neuron 2011, 70:863-885

8. Neale BM, Kou Y, Liu L, Ma'ayan A, Samocha KE, Sabo A, Lin CF, Stevens C, Wang LS, Makarov V, Polak P, Yoon S, Maguire J, Crawford EL, Campbell NG, Geller ET, Valladares O, Schafer C, Liu H, Zhao T, Cai G, Lihm J, Dannenfelser R, Jabado O, Peralta Z, Nagaswamy U, Muzny D, Reid JG, Newsham I, Wu Y, et al.: Patterns and rates of exonic de novo mutations in autism spectrum disorders. Nature 2012, 485:242-245.
9. O'Roak BJ, Vives L, Girirajan S, Karakoc E, Krumm N, Coe BP, Levy R, Ko A, Lee C, Smith JD, Turner EH, Stanaway IB, Vernot B, Malig M, Baker C, Reilly B, Akey JM, Borenstein E, Rieder MJ, Nickerson DA, Bernier R, Shendure J, Eichler EE: Sporadic autism exomes reveal a highly interconnected protein network of de novo mutations. Nature 2012, 485:246-250.

10. Iossifov I, Ronemus M, Levy D, Wang Z, Hakker I, Rosenbaum J, Yamrom B, Lee YH, Narzisi G, Leotta A, Kendall J, Grabowska E, Ma B, Marks S, Rodgers L, Stepansky A, Troge J, Andrews P, Bekritsky M, Pradhan K, Ghiban E, Kramer M, Parla J, Demeter R, Fulton LL, Fulton RS, Magrini VJ, Ye K, Darnell JC, Darnell RB, et al:: De novo gene disruptions in children on the autistic spectrum Neuron 2012, 74:285-299.

11. Girard SL, Gauthier J, Noreau A, Xiong L, Zhou S, Jouan L, Dionne-Laporte A, Spiegelman D, Henrion E, Diallo O, Thibodeau P, Bachand I, Bao JY, Tong AH, Lin CH, Millet B, Jaafari N, Joober R, Dion PA, Lok S, Krebs MO, Rouleau GA: Increased exonic de novo mutation rate in individuals with schizophrenia. Nat Genet 2011, 43:860-863.

12. Xu B, Roos JL, Dexheimer P, Boone B, Plummer B, Levy S, Gogos JA, Karayiorgou M: Exome sequencing supports a de novo mutational paradigm for schizophrenia. Nat Genet 2011, 43:864-868.

13. Awadalla P, Gauthier J, Myers RA, Casals F, Hamdan FF, Griffing AR, Côté M, Henrion E, Spiegelman D, Tarabeux J, Piton A, Yang Y, Boyko A, Bustamante C, Xiong L, Rapoport JL, Addington AM, DeLisi JL, Krebs MO, Joober R, Millet B, Fombonne E, Mottron L, Zilversmit M, Keebler J, Daoud H, Marineau C, RoyGagnon MH, Dubé MP, Eyre-Walker A, et al.: Direct measure of the de novo mutation rate in autism and schizophrenia cohorts. Am J Hum Genet 2010, 87:316-324.

14. Gauthier J, Champagne N, Lafrenière RG, Xiong L, Spiegelman D, Brustein E, Lapointe M, Peng H, Côté M, Noreau A, Hamdan FF, Addington AM, Rapoport JL, Delisi LE, Krebs MO, Joober R, Fathalli F, Mouaffak F, Haghighi AP, Néri C, Dubé MP, Samuels ME, Marineau C, Stone EA, Awadalla P, Barker PA, Carbonetto S, Drapeau P, Rouleau GA; S2D Team: De novo mutations in the gene encoding the synaptic scaffolding protein SHANK 3 in patients ascertained for schizophrenia. Proc Natl Acad Sci U S A 2010, 107:7863-7868.

15. Stefansson H, Rujescu D, Cichon S, Pietiläinen OP, Ingason A, Steinberg S, Fossdal R, Sigurdsson E, Sigmundsson T, Buizer-Voskamp JE, Hansen T, Jakobsen KD, Muglia P, Francks C, Matthews PM, Gylfason A, Halldorsson BV, Gudbjartsson D, Thorgeirsson TE, Sigurdsson A, Jonasdottir A, Jonasdottir A, Bjornsson A, Mattiasdottir S, Blondal T, Haraldsson M, Magnusdottir BB, Giegling I, Möller HJ, Hartmann A, et al.: Large recurrent microdeletions associated with schizophrenia. Nature 2008, 455:232-236.

16. Xu B, Roos JL, Levy S, van Rensburg EJ, Gogos JA, Karayiorgou M: Strong association of de novo copy number mutations with sporadic schizophrenia. Nat Genet 2008, 40:880-885.

17. Malhotra D, McCarthy S, Michaelson JJ, Vacic V, Burdick KE, Yoon S, Cichon S, Corvin A, Gary S, Gershon ES, Gill M, Karayiorgou M, Kelsoe JR, Krastoshevsky O, Krause V, Leibenluft E, Levy DL, Makarov V, Bhandari A, Malhotra AK, McMahon FJ, Nöthen MM, Potash JB, Rietschel M, Schulze TG, Sebat J: High frequencies of de novo CNVs in bipolar disorder and schizophrenia. Neuron 2011, 72:951-963.

18. Veltman JA, Brunner HG: De novo mutations in human genetic disease. Nat Rev Genet 2012, 13:565-575.

19. Ng SB, Bigham AW, Buckingham KJ, Hannibal MC, McMillin MJ, Gildersleeve HI, Beck AE, Tabor HK, Cooper GM, Mefford HC, Lee C, Turner EH, Smith JD, Rieder MJ, Yoshiura K, Matsumoto N, Ohta T, Niikawa N, Nickerson DA, Bamshad MJ, Shendure J: Exome sequencing identifies MLL2 mutations as a cause of Kabuki syndrome. Nat Genet 2010, 42:790-793.

20. Hoischen A, van Bon BW, Gilissen C, Arts P, van Lier B, Steehouwer M, de Vries P, de Reuver R, Wieskamp N, Mortier G, Devriendt K, Amorim MZ, Revencu N, Kidd A, Barbosa M, Turner A, Smith J, Oley C, Henderson A, Hayes IM, Thompson EM, Brunner HG, de Vries BB, Veltman JA: De novo mutations of SETBP1 cause Schinzel-Giedion syndrome. Nat Genet 2010, 42:483-485.

21. Conrad DF, Pinto D, Redon R, Feuk L, Gokcumen O, Zhang Y, Aerts J, Andrews TD, Barnes C, Campbell P, Fitzgerald T, Hu M, lhm CH, Kristiansson K, Macarthur DG, Macdonald JR, Onyiah I, Pang AW, Robson S, Stirrups K, Valsesia A, Walter K, Wei J; Wellcome Trust Case Control Consortium, Tyler-Smith C, Carter NP, Lee C, Scherer SW, Hurles ME: Origins and functional impact of copy number variation in the human genome. Nature 464:704-712.

22. American Psychiatric Association: Diagnostic and Statistical Manual of Mental Disorders.

23. Freitag CM: The genetics of autistic disorders and its clinical relevance a review of the literature. Mol Psychiatry 2007, 12:2-22. 
24. Sullivan PF, Kendler KS, Neale MC: Schizophrenia as a complex trait: evidence from a meta-analysis of twin studies. Arch Gen Psychiatry 2003, 60:1187-1192

25. BrainSpan: Atlas of the Developing Human Brain [www. developinghumanbrain.org]

26. Pruitt KD, Tatusova T, Klimke W, Maglott DR: NCBI Reference Sequences: current status, policy and new initiatives. Nucleic Acids Res 2009, 37(Database issue):D32-D36

27. Griswold AJ, Ma D, Cukier HN, Nations LD, Schmidt MA, Chung RH, Jaworsk JM, Salyakina D, Konidari I, Whitehead PL, Wright HH, Abramson RK, Williams SM, Menon R, Martin ER, Haines JL, Gilbert JR, Cuccaro ML, Pericak-Vance MA: Evaluation of copy number variations reveals novel candidate genes in autism spectrum disorder associated pathways. Hum Mol Genet 2012, 21:3513-3523.

28. Sato D, Lionel AC, Leblond CS, Prasad A, Pinto D, Walker S, O'Connor I, Russell C, Drmic IE, Hamdan FF, Michaud JL, Endris V, Roeth R, Delorme R, Huguet G, Leboyer M, Rastam M, Gillberg C, Lathrop M, Stavropoulos DJ, Anagnostou E, Weksberg R, Fombonne E, Zwaigenbaum L, Fernandez BA, Roberts W, Rappold GA, Marshall CR, Bourgeron T, Szatmari P, Scherer SW: SHANK1 deletions in males with autism spectrum disorder. Am J Hum Genet 2012, 90:879-887.

29. Elia J, Glessner JT, Wang K, Takahashi N, Shtir CJ, Hadley D, Sleiman PM, Zhang H, Kim CE, Robison R, Lyon GJ, Flory JH, Bradfield JP, Imielinski M, Hou C, Frackelton EC, Chiavacci RM, Sakurai T, Rabin C, Middleton FA, Thomas KA, Garris M, Mentch F, Freitag CM, Steinhausen HC, Todorov AA, Reif A, Rothenberger A, Franke B, Mick EO, et al.: Genome-wide copy number variation study associates metabotropic glutamate receptor gene networks with attention deficit hyperactivity disorder. Nat Genet 2012, 44:78-84.

30. Lázaro C, Gaona A, Ainsworth P, Tenconi R, Vidaud D, Kruyer H, Ars E, Volpini V, Estivill X: Sex differences in mutational rate and mutational mechanism in the NF1 gene in neurofibromatosis type 1 patients. Hum Genet 1996, 98:696-699.

31. Kong A, Frigge ML, Masson G, Besenbacher S, Sulem P, Magnusson G, Gudjonsson SA, Sigurdsson A, Jonasdottir A, Jonasdottir A, Wong WS, Sigurdsson G, Walters GB, Steinberg S, Helgason H, Thorleifsson G, Gudbjartsson DF, Helgason A, Magnusson OT, Thorsteinsdottir U, Stefansson $\mathrm{K}$ : Rate of de novo mutations and the importance of father's age to disease risk. Nature 2012, 488:471-475

32. Crow JF: The origins, patterns and implications of human spontaneous mutation. Nat Rev Genet 2000, 1:40-47.

33. Glaser RL, Jiang W, Boyadjiev SA, Tran AK, Zachary AA, Van Maldergem L, Johnson D, Walsh S, Oldridge M, Wall SA, Wilkie AO, Jabs EW: Paternal origin of FGFR2 mutations in sporadic cases of Crouzon syndrome and Pfeiffer syndrome. Am J Hum Genet 2000, 66:768-777.

34. Carlson KM, Bracamontes J, Jackson CE, Clark R, Lacroix A, Wells SA Jr, Goodfellow PJ: Parent-of-origin effects in multiple endocrine neoplasia type 2B. Am J Hum Genet 1994, 55:1076-1082.

35. Jadayel D, Fain P, Upadhyaya M, Ponder MA, Huson SM, Carey J, Fryer A, Mathew CG, Barker DF, Ponder BA: Paternal origin of new mutations in von Recklinghausen neurofibromatosis. Nature 1990, 343:558-559.

36. Hehir-Kwa JY, Rodríguez-Santiago B, Vissers LE, de Leeuw N, Pfundt R, Buitelaar JK, Pérez-Jurado LA, Veltman JA: De novo copy number variants associated with intellectual disability have a paternal origin and age bias. J Med Genet 2011, 48:776-778.

37. Crow JF: Age and sex effects on human mutation rates: an old problem with new complexities. J Radiat Res (Tokyo) 2006, 47 Suppl B:B75-B82.

38. Helderman-van den Enden AT, de Jong R, den Dunnen JT, HouwingDuistermaat JJ, Kneppers AL,Ginjaar HB, Breuning MH, Bakker E: Recurrence risk due to germ line mosaicism: Duchenne and Becker muscular dystrophy. Clin Genet 2009, 75: 465-472

39. Durand CM, Betancur C, Boeckers TM, Bockmann J, Chaste P, Fauchereau F, Nygren G, Rastam M, Gillberg IC, Anckarsäter H, Sponheim E, Goubran-Botros $H$, Delorme R, Chabane N, Mouren-Simeoni MC, de Mas P, Bieth E, Rogé B, Héron D, Burglen L, Gillberg C, Leboyer M, Bourgeron T: Mutations in the gene encoding the synaptic scaffolding protein SHANK3 are associated with autism spectrum disorders. Nat Genet 2007, 39:25-27.

40. Moessner R, Marshall CR, Sutcliffe JS, Skaug J, Pinto D, Vincent J, Zwaigenbaum L, Fernandez B, Roberts W, Szatmari P, Scherer SW: Contribution of SHANK3 mutations to autism spectrum disorder. Am J Hum Genet 2007, 81:1289-1297.
41. Lynch M: Rate, molecular spectrum, and consequences of human mutation. Proc Natl Acad Sci U S A 2010, 107:961-968.

42. Roach JC, Glusman G, Smit AF, Huff CD, Hubley R, Shannon PT, Rowen L, Pant KP, Goodman N, Bamshad M, Shendure J, Drmanac R, Jorde LB, Hood L, Galas $D J$ : Analysis of genetic inheritance in a family quartet by whole-genome sequencing. Science 2010, 328:636-639.

43. Lindhurst MJ, Sapp JC, Teer JK, Johnston JJ, Finn EM, Peters K, Turner J, Cannons JL, Bick D, Blakemore L, Blumhorst C, Brockmann K, Calder P, Cherman N, Deardorff MA, Everman DB, Golas G, Greenstein RM, Kato BM, Keppler-Noreuil KM, Kuznetsov SA, Miyamoto RT, Newman K, Ng D, O'Brien K, Rothenberg S, Schwartzentruber DJ, Singhal V, Tirabosco R, Upton J, et al.: A mosaic activating mutation in AKT 1 associated with the Proteus syndrome. NEngl J Med 2011, 365:611-619.

44. Amir RE, Van den Veyver IB, Wan M, Tran CQ, Francke U, Zoghbi HY: Rett syndrome is caused by mutations in X-linked MECP2, encoding methylCpG-binding protein 2. Nat Genet 1999, 23:185-188.

45. Girard M, Couvert P, Carrié A, Tardieu M, Chelly J, Beldjord C, Bienvenu T: Parental origin of de novo MECP2 mutations in Rett syndrome. Eur J Hum Genet 2001, 9:231-236

46. Trappe R, Laccone F, Cobilanschi J, Meins M, Huppke P, Hanefeld F, Engel W: MECP2 mutations in sporadic cases of Rett syndrome are almost exclusively of paternal origin. Am J Hum Genet 2001, 68:1093-1101.

47. Curtis AR, Headland S, Lindsay S, Thomas NS, Boye E, Kamakari S, Roustan P, Anvret M, Wahlstrom J, McCarthy G, Clarke AJ, Bhattacharya S: X chromosome linkage studies in familial Rett syndrome. Hum Genet 1993 90:551-555.

48. Schanen NC, Dahle EJ, Capozzoli F, Holm VA, Zoghbi HY, Francke U: A new Rett syndrome family consistent with X-linked inheritance expands the X chromosome exclusion map. Am J Hum Genet 1997, 61:634-641.

49. Wan M, Lee SS, Zhang X, Houwink-Manville I, Song HR, Amir RE, Budden S, Naidu S, Pereira JL, Lo IF, Zoghbi HY, Schanen NC, Francke U: Rett syndrome and beyond: recurrent spontaneous and familial MECP 2 mutations at $\mathrm{CpG}$ hotspots. Am J Hum Genet 1999, 65:1520-1529.

50. National Institute of Mental Health [http://www.nimh.nih.gov/index.shtml]

51. Sartorius N, Jablensky A, Korten A, Ernberg G, Anker M, Cooper JE, Day R: Early manifestations and first-contact incidence of schizophrenia in different cultures. A preliminary report on the initial evaluation phase of the WHO Collaborative Study on determinants of outcome of severe mental disorders. Psychol Med 1986, 16:909-928.

52. Laursen TM, Munk-Olsen T: Reproductive patterns in psychotic patients. Schizophr Res 2010, 121:234-240.

53. Rouleau GA, Merel P, Lutchman M, Sanson M, Zucman J, Marineau C, HoangXuan K, Demczuk S, Desmaze C, Plougastel B, et al:: Alteration in a new gene encoding a putative membrane-organizing protein causes neurofibromatosis type 2. Nature 1993, 363:515-521.

54. Trofatter JA, MacCollin MM, Rutter JL, Murrell JR, Duyao MP, Parry DM, Eldridge R, Kley N, Menon AG, Pulaski K, Haase VH, Ambrose CM, Munroe D, Bove C, Haines JL, Martuza RL, MacDonald ME, Seizinger BR, Short MP, Buckler AJ, Gusella JF: A novel moesin-, ezrin-, radixin-like gene is a candidate for the neurofibromatosis 2 tumor suppressor. Cell 1993, 75:826.

55. Knudson AG, Jr: Mutation and cancer: statistical study of retinoblastoma Proc Natl Acad Sci U S A 1971, 68:820-823.

56. Ku CS, Cooper DN: Exome sequencing: a transient technology for molecular diagnostics? Expert Rev Mol Diagn 2012, 12:211-214.

57. Clark MJ, Chen R, Lam HY, Karczewski KJ, Chen R, Euskirchen G, Butte AJ, Snyder M: Performance comparison of exome DNA sequencing technologies. Nat Biotechnol 2011, 29:908-914.

58. Lo YM, Corbetta N, Chamberlain PF, Rai V, Sargent IL, Redman CW, Wainscoat JS: Presence of fetal DNA in maternal plasma and serum. Lancet 1997, 350:485-487.

59. Sayres LC, Cho MK: Cell-free fetal nucleic acid testing: a review of the technology and its applications. Obstet Gyneco/ Surv 2011, 66:431-442.

60. St-Jacques S, Grenier S, Charland M, Forest JC, Rousseau F, Légaré F: Decisional needs assessment regarding Down syndrome prenatal testing: a systematic review of the perceptions of women, their partners and health professionals. Prenat Diagn 2008, 28:1183-1203.

61. Gattellari M, Ward JE: Will men attribute fault to their GP for adverse effects arising from controversial screening tests? An Australian study using scenarios about PSA screening. J Med Screen 2004. 11:165-169.

62. Lo YM, Hjelm NM, Fidler C, Sargent IL, Murphy MF, Chamberlain PF, Poon PM, Redman CW, Wainscoat JS: Prenatal diagnosis of fetal RhD status by 
molecular analysis of maternal plasma. NEng/ J Med 1998, 339:1734-1738.

63. Chiu RW, Akolekar R, Zheng YW, Leung TY, Sun H, Chan KC, Lun FM, Go AT, Lau ET, To WW, Leung WC, Tang RY, Au-Yeung SK, Lam H, Kung YY, Zhang X, van Vugt JM, Minekawa R, Tang MH, Wang J, Oudejans CB, Lau TK, Nicolaides $\mathrm{KH}$, Lo YM: Non-invasive prenatal assessment of trisomy 21 by multiplexed maternal plasma DNA sequencing: large scale validity study. BMJ 2011, 342:C7401.

64. Fan HC, Gu W, Wang J, Blumenfeld YJ, El-Sayed YY, Quake SR: Non-invasive prenatal measurement of the fetal genome. Nature 2012, 487:320-324.

65. Kitzman JO, Snyder MW, Ventura M, Lewis AP, Qiu R, Simmons LE, Gammill HS, Rubens CE, Santillan DA, Murray JC, Tabor HK, Bamshad MJ, Eichler EE, Shendure J: Noninvasive whole-genome sequencing of a human fetus. SciTrans/ Med 2012, 4:137ra76.

66. Kaufman L, Ayub M, Vincent JB: The genetic basis of non-syndromic intellectual disability: a review. J Neurodev Disord 2010, 2:182-209.

67. Jamain S, Quach H, Betancur C, Råstam M, Colineaux C, Gillberg IC, Soderstrom H, Giros B, Leboyer M, Gillberg C, Bourgeron T; Paris Autism Research International Sibpair Study: Mutations of the X-linked genes encoding neuroligins NLGN3 and NLGN4 are associated with autism. Nat Genet 2003, 34:27-29.

68. Boone PM, Wiszniewski W, Lupski JR: Genomic medicine and neurological disease. Hum Genet 2011, 130:103-121.

69. Genetic Information Nondiscrimination Act. Public Law 110-233, enacted 2 May 2008.

70. Aartsma-Rus A, Janson AA, Kaman WE, Bremmer-Bout M, den Dunnen JT, Baas F, van Ommen GJ, van Deutekom JC: Therapeutic antisense-induced exon skipping in cultured muscle cells from six different DMD patients. Hum Mol Genet 2003, 12:907-914.

71. Autism Resolution Ontario [http://www.autismresolutionontario.com]

72. Jacobson JW: Cost-benefit estimates for early intensive behavioral intervention for young children with autism: General model and single state case. Behavioral Interventions 1998, 13:201-226.

73. Brenner M, Johnson AB, Boespflug-Tanguy O, Rodriquez D, Goldman JE, Messing A: Mutations in GFAP, encoding glial fibrillary acidic protein, are associated with Alexander disease. Nat Genet 2001, 27:117-120.

74. DeJesus-Hernandez M, Kocerha J, Finch N, Crook R, Baker M, Desaro P, Johnston A, Rutherford N, Wojtas A, Kennelly K, Wszolek ZK, Graff-Radford N, Boylan K, Rademakers R: De novo truncating FUS gene mutation as a cause of sporadic amyotrophic lateral sclerosis. Hum Mutat 2010, 31:E1377-E1389.

75. Koide R, Kobayashi S, Shimohata T, Ikeuchi T, Maruyama M, Saito M, Yamada M, Takahashi H, Tsuji S: A neurological disease caused by an expanded CAG trinucleotide repeat in the TATA-binding protein gene: a new polyglutamine disease? Hum Mol Genet 1999, 8:2047-2053.

76. Joutel A, Dodick DD, Parisi JE, Cecillon M, Tournier-Lasserve E, Bousser MG: De novo mutation in the Notch3 gene causing CADASIL. Ann Neurol 2000, 47:388-391.

77. Lucas M, Costa AF, Montori M, Solano F, Zayas MD, Izquierdo G: Germline mutations in the CCM1 gene, encoding Krit1, cause cerebral cavernous malformations. Ann Neurol 2001, 49:529-532.

78. Bergametti F, Denier C, Labauge P, Arnoult M, Boetto S, Clanet M, Coubes $P$, Echenne B, Ibrahim R, Irthum B, Jacquet G, Lonjon M, Moreau JJ, Neau JP, Parker F, Tremoulet M, Tournier-Lasserve E; Société Française de Neurochirurgie: Mutations within the programmed cell death 10 gene cause cerebral cavernous malformations. Am J Hum Genet 2005, 76:42-51.

79. Boerkoel CF, Takashima H, Garcia CA, Olney RK, Johnson J, Berry K, Russo P, Kennedy S, Teebi AS, Scavina M, Williams LL, Mancias P, Butler IJ, Krajewski K,
Shy M, Lupski JR: Charcot-Marie-Tooth disease and related neuropathies: mutation distribution and genotype-phenotype correlation. Ann Neurol 2002, 51:190-201.

80. Valentijn $L$, Ouvrier RA, van den Bosch NH, Bolhuis PA, Baas F, Nicholson GA: Déjérine-Sottas neuropathy is associated with a de novo PMP22 mutation Hum Mutat 1995, 5:76-80

81. Claes L, Del-Favero J, Ceulemans B, Lagae L, Van Broeckhoven C, De Jonghe P: De novo mutations in the sodium-channel gene SCN1A cause severe myoclonic epilepsy of infancy. Am J Hum Genet 2001, 68:1327-1332.

82. Cannella M, Martino T, Simonelli M, Ciammola A, Gradini R, Ciarmiello A, Gianfrancesco F, Squitieri F: De novo seven extra repeat expanded mutation in the PRNP gene in an Italian patient with early onset dementia. J Neurol Neurosurg Psychiatry 2007, 78:1411-1413.

83. McNaughton D, Knight W, Guerreiro R, Ryan N, Lowe J, Poulter M, Nicholl DJ, Hardy J, Revesz T, Lowe J, Rossor M, Collinge J, Mead S: Duplication of amyloid precursor protein (APP), but not prion protein (PRNP) gene is a significant cause of early onset dementia in a large UK series. Neurobiol Aging 2012, 33:426.e13-e21.

84. Okumura A, Kurahashi H, Hirose S, Okawa N, Watanabe K: Focal epilepsy resulting from a de novo SCN1A mutation. Neuropediatrics 2007, 38:253-256.

85. Riant F, Ducros A, Ploton C, Barbance C, Depienne C, Tournier-Lasserve E: De novo mutations in ATP1A2 and CACNA1A are frequent in early-onset sporadic hemiplegic migraine. Neurology 2010, 75:967-972.

86. Viskochil D, Buchberg AM, Xu G, Cawthon RM, Stevens J, Wolff RK, Culver M, Carey JC, Copeland NG, Jenkins NA, White R, O'Connell P: Deletions and a translocation interrupt a cloned gene at the neurofibromatosis type 1 locus. Cell 1990, 62:187-192.

87. Post $B$, Ozelius $L J$, Tijssen MAJ: Juvenile rapid-onset dystonia parkinsonism due to a'de novo' mutation in the ATP1A3 gene. J Pediatr Neurol 2009, 7:171-173.

88. Weaving LS, Christodoulou J, Williamson SL, Friend KL, McKenzie OL, Archer H, Evans J, Clarke A, Pelka GJ, Tam PP, Watson C, Lahooti H, Ellaway CJ, Bennetts B, Leonard H, Gécz J: Mutations of CDKL5 cause a severe neurodevelopmental disorder with infantile spasms and mental retardation. Am J Hum Genet 2004, 75:1079-1093.

89. Borg I, Freude K, Kübart S, Hoffmann K, Menzel C, Laccone F, Firth H, Ferguson-Smith MA, Tommerup N, Ropers HH, Sargan D, Kalscheuer VM: Disruption of Netrin G1 by a balanced chromosome translocation in a girl with Rett syndrome. Eur J Hum Genet 2005, 13:921-927.

90. Rujescu D, Ingason A, Cichon S, Pietiläinen OP, Barnes MR, Toulopoulou T, Picchioni M, Vassos E, Ettinger U, Bramon E, Murray R, Ruggeri M, Tosato S, Bonetto C, Steinberg S, Sigurdsson E, Sigmundsson T, Petursson H, Gylfason A, Olason PI, Hardarsson G, Jonsdottir GA, Gustafsson O, Fossdal R, Giegling I, Möller HJ, Hartmann AM, Hoffmann P, Crombie C, Fraser G, et al:: Disruption of the neurexin $1 \mathrm{gene}$ is associated with schizophrenia. Hum Mol Genet 2009, 18:988-996.

doi:10.1186/gm372

Cite this article as: Gauthier J, Rouleau GA: De novo mutations in neurological and psychiatric disorders: effects, diagnosis and prevention. Genome Medicine 2012, 4:71. 